\title{
Arenimonas oryziterrae sp. nov., isolated from a field of rice (Oryza sativa L.) managed under a no- tillage regime, and reclassification of Aspromonas composti as Arenimonas composti comb. nov.
}

\section{Correspondence Young Ryun Chung yrchung@gnu.ac.kr}

\author{
Zubair Aslam, ${ }^{1}$ Joo Hwang Park, ${ }^{1}$ Seon Won Kim, ${ }^{1}$ Che Ok Jeon ${ }^{2}$ \\ and Young Ryun Chung ${ }^{1}$
${ }^{1}$ Division of Applied Life Science (BK 21), PMBBRC \& EB-NCRC, Gyeongsang National University, Jinju 660-701, Republic of Korea \\ ${ }^{2}$ Department of Life Science, Chung-Ang University, Seoul 156-756, Republic of Korea
}

\begin{abstract}
The taxonomic position of a novel bacterial strain, $\mathrm{YC} 6267^{\top}$ isolated from a field of rice (Oryza sativa L.) managed under a no-tillage regime in Jinju, Korea, was studied using a polyphasic taxonomic approach. Cells of the strain were Gram-stain-negative, rod-shaped and aerobic. It grew at $15-37{ }^{\circ} \mathrm{C}$ (optimum at $28^{\circ} \mathrm{C}$ ). Growth of the strain occurred between pH 5.0 and 10.0, with an optimum of $\mathrm{pH} 7.0-8.0$. The $\mathrm{G}+\mathrm{C}$ content of the total DNA was $65.8 \mathrm{~mol} \%$. The $16 \mathrm{~S}$ rRNA gene sequence of the strain was most closely related to species of the genera Arenimonas (95.6-94.4\%) and Aspromonas (95.1\%), with $<95.0 \%$ similarity to species of the genus Lysobacter and other genera of the family Xanthomonadaceae. Chemotaxonomic data (major quinone Q-8; major polar lipids phosphatidylethanolamine, phosphatidylglycerol and diphosphatidylglycerol; and major fatty acids iso- $C_{15: 0}$, iso- $C_{14: 0}$, iso- $C_{16: 0}$, and iso- $\left.C_{17: 1} \omega 9 c\right)$ supported the affiliation of strain $\mathrm{YC} 6267^{\top}$ to the genus Arenimonas. Phylogenetic analysis based on $16 \mathrm{~S}$ rRNA gene sequences and biochemical and physiological characteristics strongly supported the genotypic and phenotypic differentiation of strain YC6267 ${ }^{\top}$ from described species of the genus Arenimonas. Strain YC6267 ${ }^{\top}$, therefore, represents a novel species, for which the name Arenimonas oryziterrae sp. nov. is proposed. The type strain is YC6267 ${ }^{\top}$ (=KCTC $22247^{\top}$ $\left.=\mathrm{DSM} 21050^{\top}\right)$. In addition, the reclassification of Aspromonas composti as Arenimonas composti comb. nov. is proposed (type strain TR7-09 ${ }^{\top}=$ KCTC $12666^{\top}=$ DSM $18010^{\top}$ ). A common line of descent and a number of shared phenotypic traits support this reclassification.
\end{abstract}

The genus Arenimonas, grouped in the family Xanthomonadaceae, belonging to the Gammaproteobacteria, was proposed by Kwon et al. (2007). At present, the genus has only two species with validly published names, Arenimonas donghaensis (Kwon et al., 2007) and Arenimonas malthae (Young et al., 2007). The genus Arenimonas has the following characteristics: cells are aerobic, Gram-negative, non-spore-forming rods that are oxidase- and catalase-positive. Nitrate and nitrite are not reduced. Major isoprenoid quinone is Q-8. Predominant cellular fatty acids are iso-branched, such as iso- $\mathrm{C}_{16: 0}$, iso$\mathrm{C}_{15: 0}$ and iso- $\mathrm{C}_{17: 1} \omega 9 c$ (Kwon et al., 2007).

The bacterial communities of two rice fields, managed under conventional and no-tillage (zero-tillage) regimes,

The GenBank/EMBL/DDBJ accession number for the 16S rRNA gene sequence of strain YC6267 $7^{\top}$ is EU376961.

Three supplementary figures and one supplementary table are available with the online version of this paper. were investigated using an improved culture method. This method was based on a combination of long incubation, sonication, selection of microcolonies with the help of a magnifying lens, increasing the number of inoculation plates of each dilution, half-strength R2A agar, $25 \%$ soil extract $(\mathrm{v} / \mathrm{v})$ and some additional modifications (Hamaki et al., 2005; Janssen et al., 2002). The half-strength R2A agar consisted of $0.25 \mathrm{~g}$ yeast extract, $0.25 \mathrm{~g}$ proteose peptone no. 3, $0.25 \mathrm{~g}$ Casamino acids, $0.25 \mathrm{~g}$ glucose, $0.25 \mathrm{~g}$ soluble starch, $0.15 \mathrm{~g}$ sodium pyruvate, $0.15 \mathrm{~g}$ $\mathrm{K}_{2} \mathrm{HPO}_{4}, 0.03 \mathrm{~g} \mathrm{MgSO}_{4}$ and $15 \mathrm{~g}$ agar in 1 litre distilled water. Many taxonomically unknown bacterial strains were successfully isolated.

A total of four soil samples were collected from the rhizosphere of each field at the zero phase (pre-sowing), vegetative, reproductive and ripening phases of rice, at Gyeongsang National University farm (Daegok valley) located in the north-east of Jinju, Korea during 2007. 
Samples were collected at a depth of $15-20 \mathrm{~cm}$ and a width of 6-10 cm from five randomly selected points in each field after removing the upper 3-5 $\mathrm{cm}$ of soil, straw and debris. After sonication and serial dilution in $50 \mathrm{mM}$ phosphate buffer ( $\mathrm{pH} 7.0$ ), the samples were spread on modified halfstrength R2A agar plates. Plates were incubated at $28{ }^{\circ} \mathrm{C}$ for more than 1 month. Single colonies were purified by transferring them onto new half-strength R2A agar plates, and these were incubated again. One novel bacterial strain, YC6267 ${ }^{\mathrm{T}}$, was selected from the many strains isolated from samples collected from the rice field under the no-tillage regime at the zero growth phase. The novel strain was identified on the basis of $16 \mathrm{~S}$ rRNA gene sequence and other chemotaxonomic and genotypic characteristics, as determined for Lysobacter capsici (Park et al., 2008). It was routinely cultured on half-strength $\mathrm{R} 2 \mathrm{~A}$ agar at $28{ }^{\circ} \mathrm{C}$ and maintained in a suspension of glycerol $(15 \%, w / v)$ and half-strength R2A broth at $-70{ }^{\circ} \mathrm{C}$.

Cell morphology was observed under a Nikon light microscope at $\times 1000$ and a transmission electron microscope (Hitachi, model H-600), with cells grown for 1 day at $28{ }^{\circ} \mathrm{C}$ in half-strength R2A broth. Catalase and oxidase tests were performed using the procedures outlined by Cappuccino \& Sherman (2002). The physiological properties of strain $\mathrm{YC} 6267^{\mathrm{T}}$ were determined using previously described tests: hydrolysis of casein, aesculin, gelatin, starch and urea (Brown, 2007), hippurate (Kinyon \& Harris, 1979), elastin (Ohman et al., 1980), guanine and adenine (Wallace et al., 1995), cellulose and xylan (Ten et al., 2004) and Tween 80 (Atlas, 1993). Enzyme activities and acid production from different carbohydrates were determined by using API ZYM, ID 32E and API 20E kits, at $30{ }^{\circ} \mathrm{C}$ according to the instructions of the manufacturer (bioMérieux). API ZYM strips were read after $5 \mathrm{~h}$ incubation. The assimilation of single carbon substrates was determined by using Biolog GN2 and API 20 NE kits at $30{ }^{\circ} \mathrm{C}$ after $48 \mathrm{~h}$ incubation. Growth at different temperatures $\left(4,15,20,28,37\right.$ and $\left.42{ }^{\circ} \mathrm{C}\right)$ was tested on halfstrength R2A agar. Anaerobic growth was tested at $28{ }^{\circ} \mathrm{C}$ by pouring a thick layer of vaspar $(50 \%$ petrolatum, $50 \%$ paraffin) onto the surface of inoculated half-strength R2A broth in $35 \mathrm{ml}$ screw-capped glass tubes (Costilow, 1981). Growth at different temperatures and $\mathrm{pH}$ was assessed after 3 days of incubation. Salt tolerance was tested in halfstrength R2A broth supplemented with $0-10 \%(w / v) ~ N a C l$ after 7 days of incubation. Duplicate antibiotic-sensitivity tests were performed using filter-paper discs containing the following: tetracycline, kanamycin, ampicillin (Sigma), streptomycin and rifampicin, each at 10,50 or $100 \mu \mathrm{g}$ $\mathrm{ml}^{-1}$. Discs were placed on half-strength R2A plates spread with a suspension of strain YC6267 $7^{\mathrm{T}}$ and the plates were incubated at $28{ }^{\circ} \mathrm{C}$ for 3 days.

To determine 16S rRNA gene sequences, genomic DNA was extracted using a commercial genomic DNA extraction kit (Core Biosystem). The gene was amplified by PCR from a small amount ( $1.5 \mathrm{ng}$ ) of purified genomic DNA by using primers $27 \mathrm{~F}$ and $1492 \mathrm{R}$, and the purified PCR product was sequenced by GenoTech Inc. (Daejeon, Korea) (Lane, 1991). The 16S rRNA gene sequences were compiled using SeqMan software (DNASTAR) and the sequences of related taxa were obtained from the GenBank database. Identification of phylogenetic neighbours was initially carried out by using BLAST (Altschul et al., 1997) and FASTA (Pearson \& Lipman, 1988) programs against the database of type strains with validly published prokaryotic names (http://www.bacterio. cict.fr/). The 50 sequences with the highest scores were then selected for calculation of pairwise sequence similarity using a global alignment algorithm, which was implemented at the EzTaxon server (http://www.eztaxon.org/; Chun et al., 2007). Multiple alignments were performed for 35 closely related taxa including Escherichia coli ATCC $11775^{\mathrm{T}}$ (used as an outgroup) by using the CLUSTAL_X program (Thompson et al., 1997). Gaps were edited using the BioEdit program (Hall, 1999). Evolutionary distances were calculated using Kimura's two-parameter model (Kimura, 1983). Phylogenetic trees were constructed by using a neighbour-joining method (Saitou \& Nei, 1987) in the MEGA4 program (Tamura et al., 2007), and by maximum-parsimony (Fitch, 1971) and maximum-likelihood in PHYLIP software, version 3.6 (Felsenstein, 2002), with bootstrap values based on 1000 replications (Felsenstein, 1985).

For the measurement of $\mathrm{G}+\mathrm{C}$ content of chromosomal DNA, genomic DNA of strain YC6267 ${ }^{\mathrm{T}}$ was extracted and purified as described by Ausubel et al. (1995). It was then enzymically degraded into nucleosides, and $\mathrm{G}+\mathrm{C}$ content was determined as described by Mesbah et al. (1989) using reverse-phase HPLC. Cellular fatty acids were analysed using strain $\mathrm{YC} 6267^{\mathrm{T}}$ and reference strains grown on R2A agar for 2 days at $28{ }^{\circ} \mathrm{C}$. Cellular fatty acids were saponified, methylated and extracted according to the protocol of the Sherlock Microbial Identification System version 4.0 software (MIDI). Fatty acids analysed by GC (Hewlett Packard 6890) were identified using the Microbial Identification software package (Microbial ID). The quinone system and polar lipids were determined by HPLC and two-dimensional TLC, respectively, as described by Tindall (1990) and Lechevalier et al. (1977).

The novel strain was Gram-stain negative and non-motile. Cells were short rods $(0.4-0.5 \times 1.2-2.1 \mu \mathrm{m})$ (Supplementary Fig. S1, available in IJSEM Online) and occurred singly, in pairs and/or in clusters. Colonies grown on halfstrength R2A agar plates for 3 days were smooth, circular, yellowish to creamy-white in colour and 1-2 $\mathrm{mm}$ in diameter. Fruiting bodies were not observed. Growth was aerobic. The strain grew well on full-strength R2A agar, nutrient agar, $1.0 \%$ trypticase soy broth $(\mathrm{w} / \mathrm{v})$ plus $1.5 \%$ agar, and EMB agar, but did not grow on MacConkey agar, full-strength trypticase soy agar (TSA) or LB agar. All culture media were from Difco. Physiological characteristics and enzymic activities of strain $\mathrm{YC} 267^{\mathrm{T}}$ are summarized in the species description, and comparison of selective characteristics with related type strains is given in Table 1 . 
Table 1. Differential phenotypic characteristics between strain $\mathrm{YC} 6267^{\top}$ and closely related taxa

Strains: 1, Arenimonas oryziterrae sp. nov. YC6267 ${ }^{\mathrm{T}}$; 2, Arenimonas malthae CIP $109310^{\mathrm{T}}$; 3, Arenimonas donghaensis $\mathrm{DSM} 18148^{\mathrm{T}}$; 4 , Aspromonas composti KCTC $12666^{\mathrm{T}}$; 5, Lysobacter koreensis KCTC $12204^{\mathrm{T}}$. All data from this study unless indicated. All strains were positive for alkaline phosphatase, esterase (C-4), esterase lipase (C-8), naphthol-AS-Bl-phosphohydrolase and hydrolysis of casein, and negative for $\alpha$-galactosidase, $\beta$ galactosidase, $\alpha$-glucosidase, $\beta$-glucosidase, $\beta$-glucuronidase, $N$-acetyl- $\beta$-glucosaminidase, $\alpha$-mannosidase, $\alpha$-fucosidase. + , Positive; - , negative; $\mathrm{NA}$, not available. Indole production and hydrolysis of starch and xylan were negative in all strains.

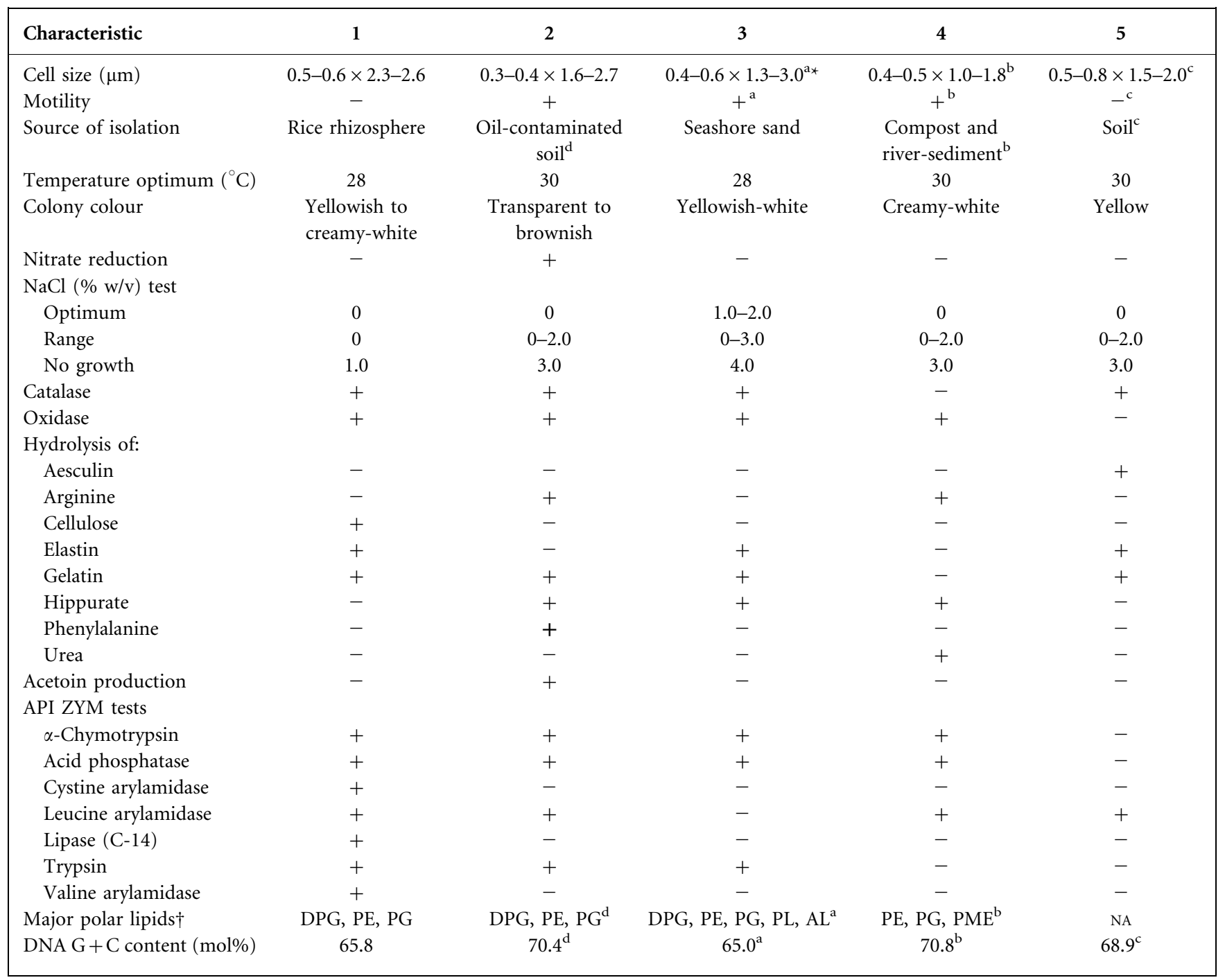

${ }^{\star}$ Data taken from: ${ }^{\mathrm{a}}$, Kwon et al., 2007; ${ }^{\mathrm{b}}$, Jin et al., 2007; ${ }^{\mathrm{c}}$, Lee et al., 2006; ${ }^{\mathrm{d}}$, Young et al., 2007.

$\dagger$ AL, unknown amino group-containing lipids; DPG, diphosphatidylglycerol; PE, phosphatidylethanolamine; PG, phosphatidylglycerol; PL, unknown phospholipid; PME, phosphatidylmethylethanolamine.

The cellular fatty acid profiles of strain $\mathrm{YC} 6267^{\mathrm{T}}$ and related Arenimonas type strains are shown in Supplementary Table S1. The major $(>5.0 \%)$ cellular fatty acids of strain $\mathrm{YC} 6267^{\mathrm{T}}$ included iso- $\mathrm{C}_{15: 0}(30.6 \%)$, iso- $\mathrm{C}_{17: 1} \omega 9 \mathrm{c}(16.1 \%)$, iso- $\mathrm{C}_{14: 0} \quad(13.2 \%)$, iso- $\mathrm{C}_{16: 0}$ $(10.2 \%)$, iso- $\mathrm{C}_{11: 0} \quad 3-\mathrm{OH} \quad(7.1 \%)$ and iso- $\mathrm{C}_{15: 1} \quad \mathrm{~F}$ $(6.2 \%)$. The major fatty acids of the novel strain were similar to those of species of the genus Arenimonas; however, some differences were found. $\mathrm{C}_{16: 1} \omega 11 \mathrm{c}$ and $\mathrm{C}_{16: 1} \omega 7 c$ alcohol were detected only in strain $\mathrm{YC} 6267^{\mathrm{T}}$.
Similarities in the pattern of major fatty acids between strain YC6267 ${ }^{\mathrm{T}}$, Aspromonas composti KCTC $12666^{\mathrm{T}}$ and species of the genus Arenimonas indicated that they might belong to the same genus. However, they could be easily differentiated from closely related strains on the basis of different amounts of the major fatty acids and the presence of some minor components (Supplementary Table S1). The major fatty acid profile of Aspromonas composti KCTC $12666^{\mathrm{T}}$ determined on R2A agar (this study) was similar to that on TSA (Jin et al. 2007), except for the presence of iso- 
$\mathrm{C}_{15: 0}$ 2-OH, $\mathrm{C}_{12: 1}$ AT 11-12 and $\mathrm{C}_{10: 0}$, which appeared in minor amounts. Lysobacter koreensis, which has $94.8 \% 16 \mathrm{~S}$ rRNA gene sequence similarity to strain $\mathrm{YC} 6267^{\mathrm{T}}$, showed a very different fatty acid profile. The following polar lipids were present: phosphatidylethanolamine, phosphatidylglycerol and diphosphatidylglycerol; and some unknown ALs (amino group-containing lipids) (Supplementary Fig. S2), which suggested the affiliation of strain $\mathrm{YC} 267^{\mathrm{T}}$ to the genus Arenimonas (Kwon et al., 2007).

The DNA G + C content of strain YC6267 ${ }^{\mathrm{T}}$ was $65.8 \mathrm{~mol} \%$. The predominant quinone was ubiquinone $8(\mathrm{Q}-8)$, as with closely related taxa. The partial $16 \mathrm{~S}$ rRNA gene sequence of strain YC6267 ${ }^{\mathrm{T}}$ was $1430 \mathrm{bp}$. Sequence similarity calculations obtained by pairwise comparisons indicated that the closest relatives of novel strain YC6267 ${ }^{\mathrm{T}}$ were Arenimonas malthae CC-JY-1 ${ }^{\mathrm{T}}$ (95.6\%), Aspromonas composti TR7-09 ${ }^{\mathrm{T}}$
(95.1\%) and Arenimonas donghaensis $\mathrm{HO} 3-\mathrm{R} 19^{\mathrm{T}}$ (94.4\%), and lower similarities $(<95.0 \%)$ were found with the other genera of the family Xanthomonadaceae. Phylogenetic trees based on the neighbour-joining (Fig. 1), maximumlikelihood (Supplementary Fig. S3) and maximum-parsimony methods (data not shown) showed clearly that strain $\mathrm{YC} 267^{\mathrm{T}}$ represented a distinct lineage close to the genus Arenimonas, supported by a high bootstrap value. Strain TR7 $-09^{\mathrm{T}}$, which was previously classified as Aspromonas composti, also formed a distinct lineage close to the genus Arenimonas (Fig. 1 and Supplementary Fig. S3). Low levels $(<97.0 \%)$ of $16 \mathrm{~S}$ rRNA gene sequence similarity between strain YC6267 ${ }^{\mathrm{T}}$ and closely related type strains of the genus Arenimonas eliminated the need for the DNA-DNA hybridization test (Stackebrandt \& Goebel, 1994; Wayne et al., 1987). The phylogenetic analysis (Fig. 1 and

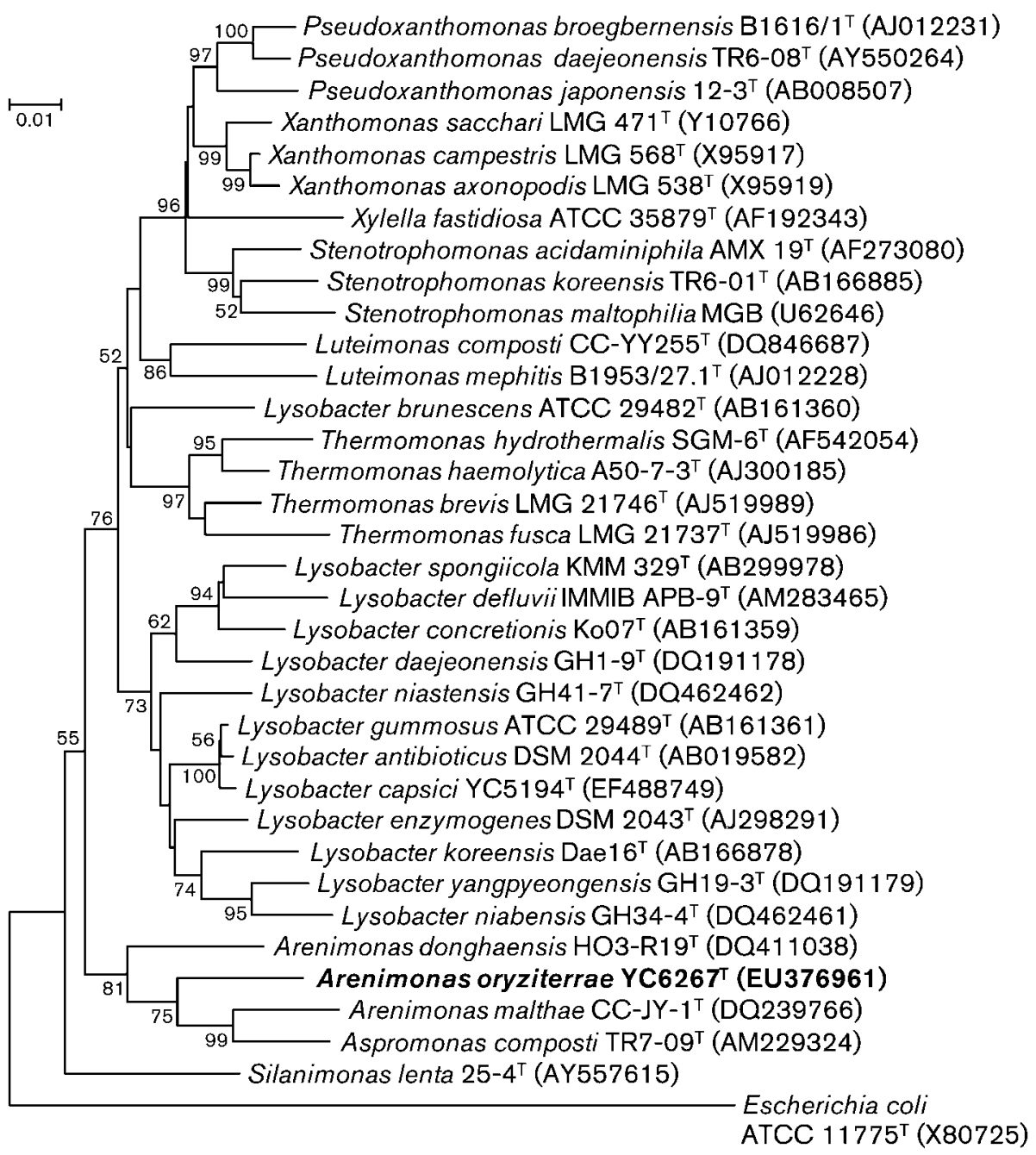

Fig. 1. Phylogenetic tree reconstructed from the comparative analysis of $16 \mathrm{~S}$ rRNA gene sequences showing the relationships of strain YC6267 ${ }^{\top}$ to closely related taxa. This phylogenetic tree was reconstructed by using the neighbour-joining method and Jukes \& Cantor evolutionary distance matrix data obtained from aligned nucleotides. Escherichia coli ATCC $11775^{\top}$ was used as an outgroup. Bootstrap values (expressed as percentages of 1000 replications) greater than $50 \%$ are shown at branch points. Bar, 1 substitution per 100 nucleotide positions. 
Supplementary Fig. S3), G + C content, other physiological and biochemical characteristics (Table 1) and fatty acid analysis profile (Supplementary Table S1) clearly distinguish strain YC6267 ${ }^{\mathrm{T}}$ from all species of the genus Arenimonas, as well as from Aspromonas composti. Thus, on the basis of the facts given above, we propose that strain $\mathrm{YC} 6267^{\mathrm{T}}$ represents a novel species of the genus Arenimonas, for which the name Arenimonas oryziterrae sp. nov. is suggested. We also propose the reclassification of Aspromonas composti, as Arenimonas composti comb. nov. Aspromonas composti was reclassified on the basis of phylogenetic analysis (Fig. 1) and shared phenotypic characteristics: Gram-stain-negative, non-spore-forming rods, oxidase positive, no reduction of nitrate and nitrite, major isoprenoid quinone Q-8. Other common and distinguishing characteristics are shown in Table 1 and Supplementary Table S1.

\section{Description of Arenimonas oryziterrae sp. nov.}

Arenimonas oryziterrae (o.ry.zi.ter'rae. L. n. oryza rice; L. n. terra earth, soil; N.L. gen. n. oryziterrae of the rice soil or field, referring to the source of isolation of the type strain).

Cells are Gram-stain-negative, aerobic, non-spore-forming, non-motile, short rods, $0.5-0.6 \mu \mathrm{m}$ wide by $2.3-2.6 \mu \mathrm{m}$ long. Occur singly, in pairs and/or in clusters. Colonies grown on half-strength $\mathrm{R} 2 \mathrm{~A}$ at $28{ }^{\circ} \mathrm{C}$ for 3 days are $1-$ $2 \mathrm{~mm}$ in diameter, yellowish to creamy-white in colour, smooth and circular in shape. The temperature range for growth is $15-37{ }^{\circ} \mathrm{C}$ with an optimum at $28{ }^{\circ} \mathrm{C}$. The $\mathrm{pH}$ range for growth is between 5.0 and 10.0, with an optimum of $\mathrm{pH}$ 7.0-8.0. Growth occurs in the absence of $\mathrm{NaCl}$ and no growth occurs in $1.0 \%(\mathrm{w} / \mathrm{v}) \mathrm{NaCl}$. Sensitive to $10 \mu \mathrm{g}$ $\mathrm{ml}^{-1}$ each of rifampicin and tetracycline and resistant to $10 \mu \mathrm{g} \mathrm{ml}{ }^{-1}$ each of kanamycin and streptomycin and $100 \mu \mathrm{g}$ ampicillin $\mathrm{ml}^{-1}$. Catalase- and oxidase-positive. Can hydrolyse casein, gelatin, elastin and cellulose but not guanine, hippurate, adenine, aesculin (in API $20 \mathrm{NE}$ ), starch or Tween 80. Can use L-aspartic acid 4-nitroanilide, Tween 40 and capric acid (in API $20 \mathrm{NE}$ ) as a single carbon source. In the Biolog GN2 kit, cannot use the following as single carbon sources: $\alpha$-cyclodextrin, dextrin, glycogen, Tween $80, \mathrm{~N}$-acetyl-D-galactosamine, $\mathrm{N}$-acetyl-D-glucosamine, adonitol, L-arabinose, D-arabitol, cellobiose, ierythritol, D-fructose, L-fucose, D-galactose, gentiobiose, $\alpha$-D-glucose, myo-inositol, $\alpha$-D-lactose, lactulose, maltose, $\mathrm{D}$-mannitol, D-mannose, melibiose, methyl $\beta$-D-glucoside, D-psicose, raffinose, L-rhamnose, D-sorbitol, sucrose, trehalose, turanose, xylitol, pyruvic acid, methyl ester, succinic acid, monomethyl ester, acetic acid, cis-aconitic acid, citric acid, formic acid, D-galactonic acid, lactone, Dgalacturonic acid, D-gluconic acid, D-glucosaminic acid, Dglucuronic acid, $\alpha$-hydroxybutyric acid, $\beta$-hydroxybutyric acid, $\gamma$-hydroxybutyric acid, $p$-hydroxyphenylacetic acid, itaconic acid, $\alpha$-ketobutyric acid, $\alpha$-ketoglutaric acid, $\alpha$ ketovaleric acid, DL-lactic acid, malonic acid, propionic acid, quinic acid, D-saccharic acid, sebacic acid, succinic acid, bromosuccinic acid, succinamic acid, glucuronamide, L-alaninamide, D-alanine, L-alanine, L-alanyl glycine,
L-asparagine, L-aspartic acid, glycyl L-aspartic acid, Lhistidine, hydroxy-L-proline, L-leucine, L-ornithine, Lphenylalanine, L-proline, L-pyroglutamic acid, D-serine, L-serine, L-threonine, DL-carnitine, urocanic acid, inosine, uridine, thymidine, phenylethylamine, putrescine, 2-aminoethanol, 2,3-butanediol, glycerol, DL- $\alpha$-glycerol phosphate, $\alpha$-D-glucose 1-phosphate, D-glucose 6-phosphate, potassium 5-ketogluconate, sodium malonate, potassium gluconate, capric acid, adipic acid, malic acid, citrate, palatinose, and L-tryptophan, while L-glutamic acid, glycyl L-glutamic acid and $\gamma$-aminobutyric acid are weakly positive. In ID $32 \mathrm{E}$ tests, acid is not produced from glucose, inositol, trehalose, D-arabitol, mannitol, maltose, adonitol, sorbitol, rhamnose, palatinose, malonate, galacturonate, 5-ketogluconate, phenol red, L-arabitol, cellobiose, sucrose or L-arabinose, and no enzymic activity against 5-bromo-4-chloro-3-indolyl $N$-acetyl- $\beta$-D-glucosaminide, 5-bromo-3-indoxyl-nonanoate, 4 -nitrophenyl $\alpha$-Dglucopyranoside, 4 -nitrophenyl $\alpha$-D-maltopyranoside, 4 -nitrophenyl $\beta$-D-glucopyranoside, 4-nitrophenyl $\beta$-Dglucuronide and 4-nitrophenyl $\alpha$-D-galactopyranoside. Also, urea is not hydrolysed, indole is not produced and nitrate is not reduced to nitrite or nitrogen gas. In the API $20 \mathrm{E}$ kit, no acid production from any substrate or enzymic activity except gelatinase. Acetoin and $\mathrm{H}_{2} \mathrm{~S}$ are not produced from sodium pyruvate and sodium thiosulfate, respectively. In the API ZYM kit, enzymic activities for alkaline phosphatase, esterase (C-4), esterase lipase (C-8), lipase (C-14), leucine arylamidase, valine arylamidase, cystine arylamidase, trypsinase, $\alpha$-chymotrypsin, acid phosphatase and naphthol-AS-Bl-phosphohydrolase, but not for $\alpha$-glucosidase, $\beta$-glucosidase, $\alpha$-galactosidase, $\beta$ galactosidase, $\beta$-glucuronidase, $N$-acetyl- $\beta$-glucosaminidase, $\alpha$-mannosidase and $\alpha$-fucosidase. Q- 8 is the major quinone. Phosphatidylethanolamine, phosphatidylglycerol and diphosphatidylglycerol are the major polar lipids. The DNA G + C content of the type strain is $65.8 \mathrm{~mol} \%$.

The type strain, YC6267 $7^{\mathrm{T}} \quad\left(=\right.$ KCTC $22247^{\mathrm{T}}=$ DSM $21050^{\mathrm{T}}$ ), was isolated from a field of rice (Oryza sativa L.) managed under a no-tillage regime in Jinju, Korea.

\section{Description of Arenimonas composti comb. nov.}

Basonym: Aspromonas composti Jin et al. 2007.

The description is the same as that provided by Jin et al. (2007) for Aspromonas composti. In addition, it can hydrolyse hippurate but not elastin. The major fatty acid profile is similar to the previously published data except that small amounts of the cellular fatty acids iso- $\mathrm{C}_{15: 0} 2-\mathrm{OH}, \mathrm{C}_{12: 1} \mathrm{AT}$ 11-12 and $\mathrm{C}_{10: 0}$ are detected on R2A agar, but not on TSA. The type strain is TR7 $-09^{\mathrm{T}}\left(=\mathrm{KCTC} 12666^{\mathrm{T}}=\mathrm{DSM} 18010^{\mathrm{T}}\right)$.

\section{Acknowledgements}

This work was supported by the Brain Korea (BK) 21 project in 20072008 and Z. A. was supported by a scholarship from the BK 21 Program, the Ministry of Education, Science and Technology, Korea. 


\section{References}

Altschul, S. F., Madden, T. L., Schaffer, A. A., Zhang, J., Zhang, Z., Miller, W. \& Lipman, D. J. (1997). Gapped BLAST and PSI-BLAST: a new generation of protein database search programs. Nucleic Acids Res 25, 3389-3402.

Atlas, R. M. (1993). Handbook of Microbiological Media. Edited by L. C. Parks. Boca Raton, FL: CRC Press.

Ausubel, F. W., Brent, R., Kingston, R. E., Moore, D. D., Seidman, J. G., Smith, J. A. \& Struhl, K. (1995). Current Protocols in Molecular Biology. New York: Wiley.

Brown, A. E. (2007). Benson's Microbiological Applications. Laboratory Manual in General Microbiology. New York: McGraw-Hill.

Cappuccino, J. G. \& Sherman, N. (2002). Microbiology: a Laboratory Manual, 6th edn. Menlo Park, CA: Benjamin/Cummings.

Chun, J., Lee, J. H., Jung, Y., Kim, M., Kim, S., Kim, B. K. \& Lim, Y. W. (2007). EzTaxon: a web-based tool for the identification of prokaryotes based on $16 \mathrm{~S}$ ribosomal RNA gene sequences. Int J Syst Evol Microbiol 57, 2259-2261.

Costilow, R. N. (1981). Biophysical factors in growth. In Manual of Methods for General Bacteriology, pp. 66-78. Edited by P. Gerhardt, R. G. E. Murray, R. N. Costilow, E. W. Nester, W. A. Wood, N. R. Krieg \& G. B. Phillips. Washington, DC: American Society for Microbiology.

Felsenstein, J. (1985). Confidence limits on phylogenies: an approach using the bootstrap. Evolution 39, 783-791.

Felsenstein, J. (2002). PHYLIP (phylogeny inference package), version 3.6a. Distributed by the author. Department of Genome Sciences, University of Washington, Seattle, USA.

Fitch, W. M. (1971). Toward defining the course of evolution: minimum change for a specific tree topology. Syst Zool 20, 406-416.

Hall, T. A. (1999). BioEdit: a user-friendly biological sequence alignment editor and analysis program for Windows 95/98/NT. Nucleic Acids Symp Ser 41, 95-98.

Hamaki, T., Suzuki, M., Fudou, R., Jojima, Y., Kajiura, T., Tabuchi, A., Sen, K. \& Shibai, H. (2005). Isolation of novel bacteria and actinomycetes using soil-extract agar medium. J Biosci Bioeng 99, 485-492.

Janssen, P. H., Yates, P. S., Grinton, B. E., Taylor, P. M. \& Sait, M. (2002). Improved culturability of soil bacteria and isolation in pure culture of novel members of the divisions Acidobacteria, Actinobacteria, Proteobacteria, and Verrucomicrobia. Appl Environ Microbiol 68, 2391-2396.

Jin, L., Kim, K. K., Im, W. T., Yang, H. C. \& Lee, S. T. (2007). Aspromonas composti gen. nov., sp. nov., a novel member of the family Xanthomonadaceae. Int J Syst Evol Microbiol 57, 1876-1880.

Kimura, M. (1983). The Neutral Theory of Molecular Evolution. Cambridge: Cambridge University Press.

Kinyon, J. M. \& Harris, D. L. (1979). Treponema innocens, a new species of intestinal bacteria, and emended description of the type strain of Treponema hyodysenteriae. Harris et al. Int J Syst Bacteriol 29, 102-109.

Kwon, S. W., Kim, B. Y., Weon, H. Y., Baek, Y. K. \& Go, S. J. (2007). Arenimonas donghaensis gen. nov., sp. nov., isolated from seashore sand. Int J Syst Evol Microbiol 57, 954-958.
Lane, D. J. (1991). 16S/23S rRNA sequencing. In Nucleic Acid Techniques in Bacterial Systematics, pp.115-175. Edited by E. Stackebrandt \& M. Goodfellow. Chichester: Wiley.

Lechevalier, M. P., De Bièvre, C. \& Lechevalier, H. (1977). Chemotaxonomy of aerobic actinomycetes: phospholipid composition. Biochem Syst Ecol 5, 249-260.

Lee, J. W., Im, W. T., Kim, M. K. \& Yang, D. C. (2006). Lysobacter koreensis sp. nov., isolated from a ginseng field. Int J Syst Evol Microbiol 56, 231-235.

Mesbah, M., Premachandran, U. \& Whitman, W. B. (1989). Precise measurement of the $\mathrm{G}+\mathrm{C}$ content of deoxyribonucleic acid by highperformance liquid chromatography. Int J Syst Bacteriol 39, 159-167.

Ohman, D. E., Cryz, S. J. \& Iglewski, B. H. (1980). Isolation and characterization of a Pseudomonas aeruginosa PAO mutant that produces altered elastase. J Bacteriol 142, 836-842.

Park, J. H., Kim, R., Aslam, Z., Jeon, C. O. \& Chung, Y. R. (2008). Lysobacter capsici sp. nov., with antimicrobial activity, isolated from the rhizosphere of pepper, and emended description of the genus Lysobacter. Int J Syst Evol Microbiol 58, 387-392.

Pearson, W. R. \& Lipman, D. J. (1988). Improved tools for biological sequence comparison. Proc Natl Acad Sci U S A 85, 2444-2448.

Saitou, N. \& Nei, M. (1987). The neighbor-joining method: a new method for reconstructing phylogenetic trees. Mol Biol Evol 4, 406425.

Stackebrandt, E. \& Goebel, B. M. (1994). Taxonomic note: a place for DNA-DNA reassociation and 16S rRNA sequence analysis in the present species definition in bacteriology. Int J Syst Bacteriol 44, 846849.

Tamura, K., Dudley, J., Nei, M. \& Kumar, S. (2007). MEGA4: molecular evolutionary genetics analysis (MEGA) software version 4.0. Mol Biol Evol 24, 1596-1599.

Ten, L. N., Im, W. T., Kim, M. K., Kang, M. S. \& Lee, S. T. (2004). Development of a plate technique for screening of polysaccharidedegrading microorganisms by using a mixture of insoluble chromogenic substrates. J Microbiol Methods 56, 375-382.

Thompson, J. D., Gibson, T. J., Plewniak, F., Jeanmougin, F. \& Higgins, D. G. (1997). The CLUSTAL_X Windows interface: flexible strategies for multiple sequence alignment aided by quality analysis tools. Nucleic Acids Res 25, 4876-4882.

Tindall, B. J. (1990). Lipid composition of Halobacterium lacusprofundi. FEMS Microbiol Lett 66, 199-202.

Wallace, R. J., Jr, Brown, B. A., Blacklock, Z., Ulrich, R., Jost, K., Brown, J. M., McNeil, M. M., Onyi, G., Steingrube, V. A. \& Gibson, J. (1995). New Nocardia taxon among isolates of Nocardia brasiliensis associated with invasive disease. J Clin Microbiol 33, 1528-1533.

Wayne, L. G., Brenner, D. J., Colwell, R. R., Grimont, P. A. D., Kandler, O., Krichevsky, M. I., Moore, L. H., Moore, W. E. C., Murray, R. G. E. \& other authors (1987). International Committee on Systematic Bacteriology. Report of the ad hoc committee on reconciliation of approaches to bacterial systematics. Int J Syst Bacteriol 37, 463-464.

Young, C. C., Kämpfer, P., Ho, M. J., Busse, H. J., Huber, B. E., Arun, A. B., Shen, F. T., Lai, W. A. \& Rekha, P. D. (2007). Arenimonas malthae sp. nov., a gammaproteobacterium isolated from an oilcontaminated site. Int J Syst Evol Microbiol 57, 2790-2793. 